\title{
Market Orientation Impacts on Business School Performance, Esprit De Corps, and Organizational Commitment: A Gender Study of AACSB Accounting Department Leaders
}

\author{
Robert L. Webster \\ Ouachita Baptist University \\ 410 Ouachita St., Box 3689 \\ Arkadelphia, AR 71998-0001, USA \\ Kevin L. Hammond \\ University of Tennessee at Martin \\ College of Business and Public Affairs \\ Martin, TN 38238, USA
}

\begin{abstract}
This manuscript reports the results of a national survey of AACSB business schools examining the impact of student market orientation on perceived business school performance, employee esprit de corps, and employee organizational commitment. The paper extends previous research by including respondent gender, examining causal models for male and female respondents and also examining Pearson correlation analyses of the consequence variables for males and females. Accounting Department Leaders (101 total, 78 male and 23 female) of AACSB Business Schools were the respondents in the study.
\end{abstract}

\section{Introduction}

Organizations including for profit businesses, governmental organizations and institutions of higher learning seek to attain and maintain high levels of performance. A specific organizational strategy and/or culture may play an important role in achieving and maintaining a high level of organizational performance. And, if this is true, it would be beneficial to be able to describe and then measure quantitatively such a strategy or culture. This research investigates these propositions and attempts to provide insight into how perceived performance and organizational commitment of AACSB member schools may be influenced or affected by such a strategy, specifically market orientation.

Aspiring high performance business schools seek accreditation from AACSB-International. AACSB standards of 2013, updated in 2016, for business school accreditation outline requirements that if met lead to accreditation thereby elevating the status of the school as well as indicating superior performance. Additionally, the Baldrige National Quality Program (BNQP 2017, 2018) has established the Baldrige Education Criteria for Performance Excellence for universities and other educational organizations. An examination of the "Baldrige Criteria for Performance Excellence" in higher education reveals that all of the components of market orientation as described in the marketing literature (Jaworski and Kohli 1993; Kohli and Jaworski 1990; Narver and Slater 1990; and Slater and Narver 1994) are incorporated into the criteria. Behaviourally, the criteria require that an educational organization maintain an awareness of and act on the current and future needs of its students, the so-called primary customers per the criteria, as well as other stakeholders. In terms of activities, the criteria require an organizational wide effort to gather, disseminate, and act on information regarding the requirements, expectations, and preferences of students and other stakeholders.

The idea that criteria for excellence in higher education should come from marketing concepts may seem revolutionary. However the idea that organizations of higher education should employ marketing strategies to improve their performance appeared in the literature as early as the 1960s. Kotler and Levy (1969) were pioneers in successfully arguing for broadening the scope of marketing (and the marketing concept) to include higher education as well as other nonbusiness organizations.

In the marketing literature, two terms, the marketing concept and market orientation are defined and described. To help provide clarity and to explain differences and relationships in these terms, the two are briefly discussed below.

- The marketing concept is a philosophy that advocates that a successful organization begins with identifying customer needs and wants, decides which needs to meet, and involves all employees in the process of satisfying customers.

- Market orientation refers to an organizational culture in which everyone in the organization is committed to the customer and adapts in a timely manner to meeting the changing needs of the customer. 
Market orientation blends a company culture dedicated to providing superior value with successfully achieving a customer focus, acquiring competitor intelligence, and maintaining interfunctional coordination. It is viewed as the implementation of the marketing concept.

The term "market orientation" refers to the extent that an organization uses the marketing concept. Kohli and Jaworski describe the processes required to engender a market orientation as a "distinct form of sustainable competitive advantage" (1990). They state that market orientation consists of "the organizationwide generation, dissemination, and responsiveness to market intelligence" (1990). Narver and Slater agreed with Kohli and Jaworski, proposing three behavioural components (customer orientation, competitor orientation, interfunctional coordination) that "comprehend the activities of marketing information acquisition and dissemination and the coordinated creation of customer value" (1990).

Kohli and Jaworski (1990); Narver and Slater (1990); Jaworski and Kohli (1993); and Slater and Narver (1994) have provided theoretical and empirical support of the positive impact of market orientation on business performance and employee commitment to the organization. Others (Hammond, Webster, and Harmon 2006; Hemsley-Brown and Oplatka 2010; and Ma and Todorovic 2011) have extended this research by examining the relationships within the context of higher education. Additionally, the Baldrige National Quality Program (BNQP) has established the Baldrige Education Criteria for Performance Excellence (2005, 2011) for universities and other educational organizations, which suggests that students are the key customers of higher education. The BNQP $(2005,2011)$ incorporates behaviours and actions indicative of high levels of market orientation as described in the marketing literature throughout the criteria for performance excellence.

This research expands the study of market orientation within higher education by introducing the potential gender differences in perceptions of organizational performance, esprit de corps, and organizational commitment as reported by Accounting Department Leaders. Previous market orientation studies concerning accounting department leaders have shown differences between leaders of private schools and public schools, and between accounting leaders and deans and vice-presidents of academic affairs (Webster and Hammond 2011, 2017; Webster, Curry, and Hammond 2018). Gender studies have become more mainstream in the business and education literature in recent years as more females have entered the workplaces of business and higher education. The 1992 book by Gray, Men are from Mars and Women are from Venus, helped spark an interest in the business and education literature for gender studies. Subsequent to the release of the book, numerous academic studies enumerating differences between the sexes have been published. For example, gender has been found to affect managers' social orientation (Marz, Powers, and Queisser 2003), differences in confidence in financial analysis (Webster, Ellis, and Bryan 2004), differences in conflict resolution methods (Brahnam et al 2005), ethical judgments (Marta, Singhapakdi, and Kraft 2008; Lund 2008), and differences in dealing with competition (Cotton et al 2015), just to list a few. Also, similar to studies within the business sector, we know that informant characteristics may act as moderators within higher education. (Hammond and Webster 2014) And, gender may be considered an informant characteristic.

We report the results of a national survey of Accounting Department Leaders at AACSB business schools. This study is an extension of previous research by Hammond, Webster, and Harmon (2006)and Webster, Hammond, and Rothwell (2010) which indicated, in part, significant $(\mathrm{p}<.001)$ regression models demonstrating causal impact of student market orientation components on three consequences: overall performance of the business school $\left(\mathrm{R}^{2}=.223\right)$, employee esprit de corps $\left(\mathrm{R}^{2}=.288\right)$, and employee organizational commitment $\left(\mathrm{R}^{2}=.231\right)$. In this study, we examine these causal relationships of market orientation toward students on these consequence variables for the key informants studied (Accounting Department Leaders of AACSB member schools located in the United States) and then by gender. Specific goals of the study are to confirm previous regression results for the Accounting Department Leaders and to confirm the regression results splitting key informants by gender.

Scales from Jaworski and Kohli (1993) to measure overall performance, esprit de corps, and organizational commitment are reworded somewhat for use within higher education. See Appendix 1. We use the Narver and Slater (1990) scale as reworded and employed by Hammond, Webster, and Harmon (2006) within higher education to measure the three components of student market orientation (customer orientation, competitor orientation, interfunctional coordination). See Appendix 2.

\section{Research Objectives and Hypotheses}

The first research objective of this study is to identify if statistically significant causal relationships exist between the student market orientation components (customer orientation, competitor orientation, inter-functional coordination) and selected consequences (overall business school performance, esprit de corps, and organizational commitment), as perceived by: (1) the entire group of Accounting Department Leaders, (2) male leaders of accounting departments within AACSB member schools, and (3) female leaders of accounting departments within AACSB member schools. 
First we examine the entire 101 respondents as a single group. We then divide the respondents into two groups, male and female, and examine the responses from each group separately. Based on market orientation theory and prior research, this first research objective is tested by way of nine hypotheses. The hypotheses are provided below along with the associated null hypotheses.

H0: Student market orientation components (customer orientation, competitor orientation, inter-functional coordination) have no statistically significant effect on the consequence variable of organizational performance as perceived by Accounting Department Leaders.

Hypothesis 1: Student market orientation components (customer orientation, competitor orientation, inter-functional coordination) have a statistically significant positive effect on the consequence variable of organizational performance as perceived by Accounting Department Leaders.

H0: Student market orientation components (customer orientation, competitor orientation, inter-functional coordination) have no statistically significant effect on the consequence variable of organizational esprit de corps as perceived by Accounting Department Leaders.

Hypothesis 2. Student market orientation components (customer orientation, competitor orientation, inter-functional coordination) have a statistically significant effect on the consequence variable of organizational esprit de corps as perceived by Accounting Department Leaders.

H0: Student market orientation components (customer orientation, competitor orientation, inter-functional coordination) have no statistically significant effect on the consequence variable of organizational commitment as perceived by Accounting Department Leaders.

Hypothesis 3: Student market orientation components (customer orientation, competitor orientation, inter-functional coordination) have a statistically significant effect on the consequence variable of organizational commitment as perceived by Accounting Department Leaders.

H0: Student market orientation components (customer orientation, competitor orientation, inter-functional coordination) have no statistically significant effect on the consequence variable of organizational performance as perceived by male Accounting Department Leaders.

Hypothesis 4: Student market orientation components (customer orientation, competitor orientation, inter-functional coordination) have a statistically significant positive effect on the consequence variable of organizational performance as perceived by male Accounting Department Leaders.

H0: Student market orientation components (customer orientation, competitor orientation, inter-functional coordination) have no statistically significant effect on the consequence variable of organizational esprit de corps as perceived by male Accounting Department Leaders.

Hypothesis 5: Student market orientation components (customer orientation, competitor orientation, inter-functional coordination) have a statistically significant effect on the consequence variable of organizational esprit de corps as perceived by male Accounting Department Leaders.

H0: Student market orientation components (customer orientation, competitor orientation, inter-functional coordination) have no statistically significant effect on the consequence variable of organizational commitment as perceived by male Accounting Department Leaders.

Hypothesis 6: Student market orientation components (customer orientation, competitor orientation, inter-functional coordination) have a statistically significant effect on the consequence variable of organizational commitment as perceived by male Accounting Department Leaders.

H0: Student market orientation components (customer orientation, competitor orientation, inter-functional coordination) have no statistically significant effect on the consequence variable of organizational performance as perceived by female Accounting Department Leaders.

Hypothesis 7:Student market orientation components (customer orientation, competitor orientation, inter-functional coordination) have a statistically significant positive effect on the consequence variable of organizational performance as perceived by female Accounting Department Leaders.

H0: Student market orientation components (customer orientation, competitor orientation, inter-functional coordination) have no statistically significant effect on the consequence variable of organizational esprit de corps as perceived by female Accounting Department Leaders. 
Hypothesis 8: Student market orientation components (customer orientation, competitor orientation, inter-functional coordination) have a statistically significant effect on the consequence variable of organizational esprit de corps as perceived by female Accounting Department Leaders.

H0: Student market orientation components (customer orientation, competitor orientation, inter-functional coordination) have no statistically significant effect on the consequence variable of organizational commitment as perceived by female Accounting Department Leaders.

Hypothesis 9: Student market orientation components (customer orientation, competitor orientation, inter-functional coordination) have a statistically significant effect on the consequence variable of organizational commitment as perceived by female Accounting Department Leaders.

Our second research objective is to examine the influence of key informant gender on identified causal relationships as discussed above between student market orientation components and selected performance measures within AACSB member schools. Again, we employ Accounting Department Leaders as the research group. Previous gender research indicates generally that females are more collaborative than males in group planning, strategizing and decision making (Bart and McQueen 2013; Caprino 2016). As market orientation is a collaborative strategy that helps to create a collaborative organizational culture, we address the research question by theorizing that females are more perceptive regarding the possible benefits of student market orientation. We thus hypothesize that any identified impact of the market orientation components on the consequent variables under study are such that the female group perceives/identifies stronger causal relationships. The resulting three hypotheses appear below (Hypotheses 10-12) along with associated null hypotheses.

H0: The impact of student market orientation components (customer orientation, competitor orientation, interfunctional coordination) on the consequence variable of organizational performance will be perceived/identified as lower by female Accounting Department Leaders compared to male Accounting Department Leaders.

Hypothesis 10: The impact of student market orientation components (customer orientation, competitor orientation, inter-functional coordination) on the consequence variable of organizational performance will be perceived/identified as greater by female Accounting Department Leaders compared to male Accounting Department Leaders.

H0: The impact of student market orientation components (customer orientation, competitor orientation, interfunctional coordination) on the consequence variable of esprit de corps will be perceived/identified as lower by female Accounting Department Leaders compared to male Accounting Department Leaders.

Hypothesis 11: The impact of student market orientation components (customer orientation, competitor orientation, inter-functional coordination) on the consequence variable of esprit de corps will be perceived/identified as greater by female Accounting Department Leaders compared to male Accounting Department Leaders.

H0: The impact of student market orientation components (customer orientation, competitor orientation, interfunctional coordination) on the consequence variable of organizational commitment will be perceived/identified as lower by female Accounting Department Leaders compared to male Accounting Department Leaders.

Hypothesis 12: The impact of student market orientation components (customer orientation, competitor orientation, inter-functional coordination) on the consequence variable of organizational commitment will be perceived/identified as greater by female Accounting Department Leaders compared to male Accounting Department Leaders.

\section{Methodology}

Data for the study were collected by way of a mailed survey. Mailing addresses for the survey group were obtained from a purchased mailing list which contained only postal addresses, not telephone numbers or email addresses. Survey instruments along with a cover letter were mailed to Accounting Department Leaders of AACSB member schools located in the United States. As key informants (Campbell 1955; Phillips 1981), the addressees were asked to complete the surveys and return them in business reply envelopes that were provided. Of the total survey instruments mailed, 101(21\%) were completed and returned. Of the 101 returned surveys, 78 were from male respondents and 23 were from female respondents. Anticipating that some respondents may have difficulty with the concept of students as markets (or customers or even stakeholders) of higher education, we did not use those terms in the survey. We simply referred to students as students, and also avoided the terms marketing, marketing concept, and market orientation in the survey and the cover letter.

Scores are calculated for all variables. We examine regression models for the market orientation components (independent variables) and each of the consequence measures (dependent variables) of overall performance, employee esprit de corps, and employee organizational commitment for Accounting Leaders overall and then by gender, addressing the first research question and the nine hypotheses enumerated above. 
The second research question and associated three hypotheses are addressed by further examination of the results of the regression models. Generally, we anticipate higher F values, with greater statistical significance and higher Adjusted Rsquare measures for the female group. We compare the models used for hypotheses 4 and 7 in addressing hypothesis 10 for organizational performance. We likewise compare the models for esprit de corps (hypotheses 5 and 8) and organizational commitment (hypotheses 6 and 9) in addressing hypotheses 11 and 12, respectively.

All items used to measure student market orientation, employee esprit de corps, and employee organizational commitment were measured with a seven point Likert response scale, ranging from one (1) "not at all" to seven (7) "to an extreme extent." Narver and Slater's (1990) market orientation (MKTOR, modified) scale consists of several questions addressing specific behaviours and activities which measure the extent that the organization (university, in this case) applies the marketing concept. The questions address concerns raised by Barksdale and Darden (1971) that market orientation is properly measured in terms of behaviours and activities instead of "philosophical notions." We combine the questions to form three subscales as identified by Narver and Slater (1990) that measure the market orientation components (customer orientation, competitor orientation, interfunctional coordination) used in this study. Employee esprit de corps and organizational commitment are described by Jaworski and Kohli (1993) as "the extent to which a team spirit prevailed in the organization," and the extent that "employees were fond of the organization, saw their future tied to that of the organization, and were willing to make personal sacrifices," respectively.

"Overall performance" is measured using the subjective Jaworski and Kohli (1993) two-item measure that is based on executive opinion of performance. No specific performance goals are assumed for the respondents. Each respondent answered the two questions about actual recent overall performance relative to the expectations and performance goals of that particular business school on a scale of $1=$ poor to $7=$ excellent. Slater and Narver (1994) defend the use of subjective performance measures, noting that the measures "are used commonly in research on private companies or business units of large corporations." They also note the "strong correlation between subjective assessments and their objective counterparts" that has been indicated in previous research.

The scales were subjected to reliability analysis and exploratory factor analysis prior to further analysis (Churchill 1979; Peter 1979). The scales are indicated to be reliable (with alphas ranging from .76 to .87 and item-to-total correlations from .37 to .79). Exploratory factor loadings range from .4 to .9. The Pearson correlation coefficient for the two overall performance items is .757(sign. .000), indicating reliability for this two-item scale. The possibility of nonresponse bias was investigated by comparing early and late respondents (Armstrong and Overton 1977). The tests indicated no significant differences between early and late respondents (at the .10 level of significance).

Also, Berdie (1989) found that, even in the event of nonresponse bias in mail surveys, typically the bias did not alter the survey findings.

\section{Results and Implications}

We calculate and provide descriptive statistics (mean and standard deviation) for each variable in total and by gender in Table 1.Recall that these response scales range from a low of "1" to a high of "7," with "4" as the midpoint. Note from the tables that male and female respondents reported very similar levels for all three market orientation components and for all three performance indicators.

Table 1 Descriptive Statistics by Total and by Gender

\begin{tabular}{|l|l|l|l|}
\hline \multirow{2}{*}{ Accounting Department Leaders } & $\begin{array}{l}\text { Customer } \\
\text { Orientation }\end{array}$ & $\begin{array}{l}\text { Competitor } \\
\text { Orientation }\end{array}$ & $\begin{array}{l}\text { Interfunctional } \\
\text { Coordination }\end{array}$ \\
\cline { 2 - 4 } Male & Mean (N) Std Dev & Mean (N) Std Dev & Mean (N) Std Dev \\
\hline \multirow{2}{*}{ Female } & $\mathbf{4 . 4 4 ( 1 0 1 ) . 9 8}$ & $\mathbf{3 . 3 8}(\mathbf{1 0 1}) \mathbf{1 . 2 8}$ & $\mathbf{3 . 7 0}(\mathbf{1 0 1}) \mathbf{1 . 1 6}$ \\
& $4.47(78) .96$ & $3.38(78) 1.27$ & $3.72(78) 1.15$ \\
& $4.36(23) 1.06$ & $3.40(23) 1.37$ & $3.64(23) 1.21$ \\
\hline & Overall Business & Employee & Employee \\
& School & Esprit de Corps & $\begin{array}{l}\text { Organizational } \\
\text { Commitment }\end{array}$ \\
\hline Accounting Department Leaders & Mean (N) Std Dev & Mean (N) Std Dev & Mean (N) Std Dev \\
\cline { 2 - 5 } Male & $\mathbf{5 . 2 8 ( 1 0 1 ) ~} \mathbf{1 . 0 0}$ & $\mathbf{3 . 9 8}(\mathbf{1 0 1}) .95$ & $\mathbf{3 . 9 9}(\mathbf{1 0 1}) .70$ \\
Female & $5.27(78) 1.02$ & $3.96(78) 1.00$ & $4.03(78) .71$ \\
\hline
\end{tabular}


Results of the regression analyses are presented in Table 2 for Accounting Leaders overall, and also for males and females separately. A total of nine regression analyses are reported altogether. The separate analyses by gender differ in some respects from the overall analysis and also from each other.

Table 2. Tests for Main Effects - Results of Regression Analyses Regression Coefficients (Standard Errors)

\begin{tabular}{|c|c|c|c|}
\hline & Dependent Va & bles & \\
\hline & $\begin{array}{l}\text { Overall } \\
\text { Performance }\end{array}$ & $\begin{array}{l}\text { Employee } \\
\text { Esprit de } \\
\text { Corps }\end{array}$ & $\begin{array}{l}\text { Employee } \\
\text { Org. } \\
\text { Commitment }\end{array}$ \\
\hline $\begin{array}{l}\text { ACCOUNTING DEPT.LEADERS OVERALL } \\
\text { Student Mkt. Orientation - Customer Orientation } \\
\text { Student Mkt. Orientation - Competitor Orientation } \\
\text { Student Mkt. Orientation - Coordination } \\
\text { F } \\
\text { Adjusted } \mathrm{R}^{2}\end{array}$ & $\begin{array}{l}.251^{1}(.125) \\
.377^{2}(.100) \\
-.046(.107) \\
13.59^{3} \\
.274\end{array}$ & $\begin{array}{l}.338^{2}(.112) \\
.300^{1}(.089) \\
.040(.096) \\
19.42^{3} \\
.356\end{array}$ & $\begin{array}{l}.151(.090) \\
.182(.072) \\
.233(.077) \\
10.76^{3} \\
.226\end{array}$ \\
\hline $\begin{array}{l}\text { MALE DEPT. LEADERS } \\
\text { Student Mkt. Orientation - Customer Orientation } \\
\text { Student Mkt. Orientation - Competitor Orientation } \\
\text { Student Mkt. Orientation - Coordination } \\
\text { F } \\
\text { Adjusted } \mathrm{R}^{2}\end{array}$ & $\begin{array}{l}.245(.150) \\
.348^{1}(.127) \\
-.052(.136) \\
8.48^{3} \\
.226\end{array}$ & $\begin{array}{l}.396^{2}(.128) \\
.367^{2}(.108) \\
-.050(.116) \\
19.05^{3} \\
.413\end{array}$ & $\begin{array}{l}.235(.106) \\
.298(.090) \\
-.004(.097) \\
7.52^{3} \\
.202 \\
\end{array}$ \\
\hline $\begin{array}{l}\text { FEMALE DEPT. LEADERS } \\
\text { Student Mkt. Orientation - Customer Orientation } \\
\text { Student Mkt. Orientation - Competitor Orientation } \\
\text { Student Mkt. Orientation - Coordination } \\
\text { F } \\
\text { Adjusted } \mathrm{R}^{2}\end{array}$ & $\begin{array}{l}.260(.239) \\
.474(.169) \\
-.004(.177) \\
5.43^{2} \\
.376\end{array}$ & $\begin{array}{l}.167(.233) \\
.167(.165) \\
.239(.172) \\
2.06 \\
.126\end{array}$ & $\begin{array}{l}-.260(.130) \\
.148(.092) \\
.868^{3}(.096) \\
11.26^{3} \\
.583\end{array}$ \\
\hline
\end{tabular}

F-values associated with each of the consequence variables are significant considering regression models when all of the Accounting Department Leaders are considered (Hypotheses1-3). More specifically, results indicate statistically significant effects for the customer orientation and competitor orientation components, but not for the interfunctional coordination component of student market orientation. Student customer orientation impacts overall performance $(\mathrm{p}<.05)$ and also employee esprit de corps $(\mathrm{p}<.01)$. Likewise, the competitor orientation component is indicated to impact overall performance $(\mathrm{p}<.01)$ and employee esprit de corps $(\mathrm{p}<.05)$. No statistically significant effects are indicated for the interfunctional coordination component.

In fact, though unexpected from theory and not statistically significant, results indicate an inverse effect for the interfunctional coordination component. However, all three models are statistically significant $(\mathrm{p}<.001)$. Though some of the results regarding individual market orientation components were unexpected, and no individual component demonstrated a statistically significant impact on employee organizational commitment, Hypotheses 1, 2 and 3 are all supported.

Addressing Hypotheses 4-6, regression models for male Accounting Department Leaders are all indicated to be statistically significant ( $\mathrm{p}<.001$ ). Similarly to results discussed above (and possibly due to males being the larger group), results for the male Accounting Leaders indicate statistically significant effects for the customer orientation and competitor orientation components, but not for the interfunctional coordination component of student market orientation. Specifically, though, results suggest that student customer orientation only impacts employee esprit de corps $(\mathrm{p}<.01)$. The competitor orientation component is indicated to impact both overall performance $(\mathrm{p}<.05)$ and employee esprit de corps $(\mathrm{p}<.01)$. Similarly to above, though unexpected from theory and not statistically significant, results indicate inverse effects for the interfunctional coordination component. With statistically significant F-values for the three regression models, Hypotheses 4, 5 and 6 are all supported. Though similar in some respects to regression models for the males, results of the regressions for the female respondents (Table 2) are considerably different in many respects. Notably, the model for employee esprit de corps is not indicated to be statistically significant and none of the individual student market orientation components are indicated to impact esprit de corps at a statistically significant level ( $\mathrm{p}<.05$ or better). 
The models for organizational performance and employee organizational commitment are indicated to be statistically significant. Individually, however, the customer orientation and competitor orientation components of student market orientation are not indicated to impact any of the proposed consequences of market orientation for the female Accounting Department Leaders. Interfunctional coordination is indicated to affect employee organizational commitment $(\mathrm{p}<.001)$ only. Note also from the models the unexpected (and statistically insignificant) inverse effects of the interfunctional coordination component on overall performance and the customer orientation component on organizational commitment. Hypotheses 7 and 9 are supported; the analysis fails to support Hypothesis 8 .

Regarding Hypothesis 10, the F value is higher and more statistically significant in the model for males, but the Adjusted R-square measure is higher for the female group, indicating possibly more explanatory power for that model though not as statistically significant. Both measures ( $F$ value and Adjusted R-square) are higher for the male group than for the female group when considering the models for employee esprit de corps. On the other hand, both measures ( $F$ value and Adjusted R-square) are higher for the female group than for the male group when considering the impact of the market orientation components on organizational commitment.

From above, we conclude that Hypothesis 10 is partially supported, Hypothesis 11 is not supported, and Hypothesis 12 is supported. These results were somewhat unexpected and seem to point to an opportunity for additional study which may hold the explanation. Note that, given that the student customer orientation component demonstrates an unexpected negative regression coefficient for the female group, even the "expected" support shown for Hypothesis 12 contains a surprising outcome.

Finally, to provide greater understanding of relationships the consequence variables may have with each other, we perform and present (Table 3) Pearson correlation analyses between the three selected consequence variables. These results do not address the hypotheses directly but help to explain why the regression models may be important.

Table 3. Pearson Correlation Analyses - Consequence Variables Coefficients (Significance)

\begin{tabular}{|c|c|c|}
\hline $\begin{array}{l}\text { ACCOUNTING DEPT. LEADERS } \\
\text { OVERALL }\end{array}$ & Employee Esprit de Corps & $\begin{array}{l}\text { Employee Organizational } \\
\text { Commitment }\end{array}$ \\
\hline Overall Bus. School Performance & $\begin{array}{l}.456(.000) \\
\mathrm{N}=101\end{array}$ & $\begin{array}{l}.313(.001) \\
\mathrm{N}=101\end{array}$ \\
\hline Employee Esprit de Corps & & $\begin{array}{l}.596(.000) \\
\mathrm{N}=101\end{array}$ \\
\hline $\begin{array}{l}\text { ACCOUNTING DEPT. LEADERS } \\
\text { MALE }\end{array}$ & Employee Esprit de Corps & $\begin{array}{l}\text { Employee Organizational } \\
\text { Commitment }\end{array}$ \\
\hline Overall Bus. School Performance & $\begin{array}{l}.446(.000) \\
\mathrm{N}=78\end{array}$ & $\begin{array}{l}.274(.015) \\
\mathrm{N}=78\end{array}$ \\
\hline Employee Esprit de Corps & & $\begin{array}{l}.628(.000) \\
\mathrm{N}=78\end{array}$ \\
\hline $\begin{array}{l}\text { ACCOUNTING DEPT. LEADERS } \\
\text { FEMALE }\end{array}$ & Employee Esprit de Corps & $\begin{array}{l}\text { Employee Organizational } \\
\text { Commitment }\end{array}$ \\
\hline Overall Bus. School Performance & $\begin{array}{l}.504(.014) \\
\mathrm{N}=23\end{array}$ & $\begin{array}{l}.487(.018) \\
\mathrm{N}=23\end{array}$ \\
\hline Employee Esprit de Corps & & $\begin{array}{l}.493(.017) \\
\mathrm{N}=23\end{array}$ \\
\hline
\end{tabular}

As mentioned above, we examine Pearson correlations between the consequence variables for the overall group, and for male and female Department Leaders in an effort to better understand the relationships between these three measures of business school performance. We find that, though not necessarily causally related, they are indeed correlated. Schools that demonstrate higher levels of performance in one of the variables also tend to have higher levels of performance in the other variables. Similarly, schools with lower levels in one performance variable also have lower levels in both of the other variables. We offer that these correlations might be used to help understand some of the implications of our other results. For example, even esprit de corps in the case of the female group (nonsignificant model per the results for Hypothesis 8, Table 2) may be impacted indirectly through its positive correlation with the other performance variables. We should strive for higher levels of business school performance, and one way to do that is to enhance levels of student market orientation at our universities. Male and female leaders differ in their perceptions of the causal relationships. Within AACSB schools, gender matters when attempting to ascertain the impact of the components of student market orientation on overall business school performance, esprit de corps, and organizational commitment. 
Better understanding of these differences in perception may provide important insights into the organizational dynamics that are in play at universities, and provide an opportunity to maximize student market orientation and the various performance-related consequences of market orientation.

As demonstrated, gender impacts perception in judgments of organizational properties. Results of this study indicate that key informant gender should be considered in studies of student market orientation and its consequences within higher education. Specifically, gender is indicated to impact the results for all three of the examined models (consequence variables of overall business school performance, esprit de corps, and organizational commitment).

In view of Narver and Slater (1990) and Kohli and Jaworski (1993) findings that enhanced levels of market orientation will improve the competitive advantage of organizations, business schools appear to be organizations ripe to take advantage of the market orientation concept. Focus on creating a market orientation culture should serve both schools and their various stakeholders, not just students, in more effectively achieving the organizational mission. As students may be viewed as the most visible of the numerous markets served, market orientation efforts focused at students would seem to have the potential for the fastest and highest payoff. Examples of such payoffs, all of which might correctly be viewed as performance indicators might include:

1. A potential increase in enrollment within the business school and accounting department

2. A potential increase in the hit rate (increase in percent of applicants that actually enroll)

3. A potential increase in the number of business/accounting majors

4. A potential increase in the retention rate of current business/accounting students

5. A potential increase in the graduation rate of business school students

\section{Study Limitations and Suggestions for Future Research}

The findings of this study can be generalized to others within higher education and also outside of higher education. We urge caution, however, in applying the findings due to the limitations of the sampling frame (AACSB member schools, located in the United States). Also, we surveyed Accounting Leaders only. Employees at other levels (vice presidents or vice chancellors for academics, deans, and faculty) may have different perceptions. Accordingly, results of the study might be different if examined from one of these other levels of the organization. These limitations present an opportunity for further research; the study could be repeated at other levels of the organization, or in other types of organizations.

Additionally, gender may not be the only respondent demographic that impacts the relationships between market orientation and its consequences within higher education. Future studies could examine the possible effect of highest academic degree, major field of study, years of experience, or length of service at the university. Various respondent demographics may also be found to affect the relationships outside of academia as well.

Finally, results of this study suggest several questions for future research. Why do female accounting department leaders perceive generally lower levels of student customer orientation for higher levels of business school organizational commitment? Since student market orientation is almost always shown to positively impact overall performance, employee organizational commitment and employee esprit de corps, what can universities do to increase student market orientation (and thus performance)? Why do male and female accounting department leaders perceive employee esprit de corps, and its relationship with student market orientation, so differently? Why is the interfunctional coordination component of student market orientation within universities not more firmly and uniformly related to business school performance, as expected from research?

\section{References}

AACSB International - The Association to Advance Collegiate Schools of Business (2013 updated 2016), "Eligibility Procedures and Accreditation Standards for Business Accreditation, AACSB International, Tampa, FL.

Armstrong, J.S. and Overton, T.S. (1977), "Estimating Nonresponse Bias in Mail Surveys," Journal of Marketing Research, 14 (August), 396-402.

Baldrige National Quality Program (20017 2018), "Baldrige Education Criteria for Performance Excellence,” National Institute of Standards and Technology, Gaithersburg, MD, (available at www.quality.nist.gov/Education_Criteria.htm).

Barksdale, H.C. and Darden B. (1971), “Marketers' Attitude toward the Marketing Concept,” Journal of Marketing, 35 (October), 29-36.

Bart, C. and McQueen, G. (2013), "Why Women make Better Directors," International Journal of Business Governance and Ethics, Vol. 8. No. 1, 93-99.

Berdie, D. R. (1989), "Reassessing the Value of High Response Rates to Mail Surveys," Marketing Research, 1, 52-54. 
Brahnam, S.D., Margario, T.M., Hignite, M.A., Barrier, T.B., and Chin, J. M., (2005), “A Gender Based Categorization for Conflict Resolution,” Journal of Management Development, Vol 24. Is. 3, 197-208.

Campbell, D. T. (1955), “The Informant in Quantitative Research,” American Journal of Sociology,60, 339-342.

Caprino, K., (2016), "How Decision-Making is Different between Men and Women and Why it Matters in Business," Forbes.com, May 12, 2016, 10:12 am.

Cotton,C.S., Li, C., McIntyre, F., and Price, J.P., (2015), "Which Explanations for Gender Differences in Competition are Consistent with a Single Theoretical Model?" Journal of Behavioral and Experimental Economics," Vol. 59, Dec. 2015, 56-67.

Campbell, D.T. (1955), “The Informant in Quantitative Research,” The American Journal of Sociology, Vol. 60, 339342.

Churchill, G.A. (1979), “A Paradigm for Developing Better Measures of Marketing Constructs," Journal of Marketing Research, 16 (February), 64-73.

Gray, J., (1992), Men are from Mars, Women are from Venus, Harper-Collins Publishers, NY, NY.

Hammond, K.L., Webster, R.L. and Harmon H.A. (2006), "Market Orientation, Top Management Emphasis, and Performance within University Schools of Business: Implications for Universities," Journal of Marketing Theory and Practice, 14 (winter), 69-85.

Hammond, K.L., and Webster, R.L., (2014),"Informant Characteristics as Moderators in Higher Education Research," Marketing Intelligence and Planning, Vol. 32, No.4, 398-412.

Hemsley-Brown, J. and Oplatka, I. (2010), "Market Orientation in Universities: A Comparative Study of two National Higher Education Systems," International Journal of Educational Management, Vol. 24 No. 3, 201-220.

Jaworski, B. J. and Kohli, A.K. (1993), "Market Orientation: Antecedents and Consequences," Journal of Marketing, 57 (July), 53-70.

Kohli, A.K. and. Jaworski, B.J. (1990), "Market Orientation: the Construct, Research

Proposition, and Managerial Implications," Journal of Marketing, 54 (April), 1-18.

Kotler, P. (1980) Marketing Management: Analysis. Planning and Control, (4th Ed.) Englewood

Cliffs, NJ: Prentice-Hall, Inc.

Lund, D. (2008), “Gender Differences in Ethics Judgment of Marketing Professionals in the United States, ” Journal of Business Ethics, 77 (4), 501-515.

Ma, J. and Todorovic, Z. (2011), "Making Universities Relevant: Market Orientation as a Dynamic Capability within Institutions of Higher Learning," Academy of Marketing Studies Journal, 15(2), 1-15.

Marta, J., Singhapakdi A., and Kraft K. (2008), "Personal Characteristics Underlying Ethical Decisions in Marketing Situations: A Survey of Small Business Managers," Journal of Small Business Management, 46 (4), 589-606.

Marz, J.W., Powers T.L., and Queisser T. (2003), "Corporate and Individual Influences on Managers' Social Orientation," Journal of Business Ethics, 46 (1), 1-11.

Narver, J.C. and Slater S.F. (1990), "The Effect of a Market Orientation on Business

Profitability," Journal of Marketing, 54 (October), 20-35.

Peter, J.P. (1979), "Reliability: a Review of Psychometric Basics and Recent Marketing Practices," Journal of Marketing Research, 16 (February), 6-17.

Phillips, L.W. (1981), "Assessing Measurement Error in Key Informant Reports: A Methodological Note on Organizational Analysis in Marketing," Journal of Marketing Research, 18 (November), 395-415.

Slater, S.F. and Narver J.C (1994), "Does Competitive Environment Moderate the Market Orientation - Performance Relationship?" Journal of Marketing, 45 (Summer), 9-16.

Webster, R.L., Ellis, T.S., and Bryan, B.J. (2004), "Similarities and Differences between the Sexes in Financial Analysis and Self-Confidence," Academy of Accounting and Financial Studies Journal, Vol.8, Is. 1, 89-100.

Webster, R.L., Hammond, K.L., and Rothwell, J.C. (2010), "Customer and Market Orientation within AACSB Member Business Schools: Comparative Views from Three Levels of Administrators," American Journal of Business Education, Vol.3, No. 7, 79-91.

Webster, R.L. and Hammond, K.L., (2011), "Are Students and their Parents Viewed as Customers by AACSBInternational Member Schools? Survey Results and Implications for University Business School Leaders," Academy of Educational Leadership Journal, Vol. 15, No.2, 1-17.

Webster, R.L. and Hammond, K.L., (2017), "How a Focus on Employers may Improve Business School Performance: Perceptions of Accounting Department Chairpersons, Deans, and Vice-presidents of AACSB Business Schools," International Journal of Business, Humanities, and Technology, Vol. 7, No. 4, 15-22.

Webster, R.L., Curry, J.A., and Hammond, K.L., (2018), "Market Orientation toward Students and Organizational Performance: Perceptions of Accounting Department Chairpersons of Public and Private Business Schools Belonging to AACSB," International Journal of Business and Social Science, Vol.9, No. 6, June 2018, 1-9. 


\section{APPENDIX 1}

Organizational Commitment, Esprit de Corps, and Overall Performance Survey Questions Sent to Accounting Department Leaders of AACSB Schools of Business

7 point scale

Organizational Commitment:

1. Employees feel as if their future is intimately linked to that of the school of business.

being.

2. Employees would be happy to make personal sacrifices if it were important for the business school's well-

3.The bonds between the school of business and its employees are weak.

4. In general, employees are proud to work for the school of business.

5. Employees often go above and beyond the call of duty to ensure the school of business's well-being.

6. Our people have little or no commitment to the school of business.

7. It is clear that employees are fond of the business school.

Esprit de Corps:

1. People in the business school are genuinely concerned about the needs and problems of each other.

2. A team spirit pervades all ranks in the business school.

3. Working for the business school is like being a part of a big family.

4. People in the business school feel emotionally attached to each other.

5. People in the business school feel like they are "in it together."

6. The business school lacks an "esprit de corps."

7. People in the business school view themselves as independent individuals who have to tolerate others around them.

Overall Performance:

1. The overall performance of the business school last year.

2. The overall performance of the business school last year relative to major competitors.

\section{APPENDIX 2}

Market Orientation Survey Questions Sent to

Accounting Department Leaders of AACSB Schools of Business

7 point scale

1.Our objectives are driven by satisfaction of our students.

2.We measure satisfaction of our students systematically and frequently.

3.Those responsible for recruiting students regularly share information within our business school/institution concerning competitor's strategies.

4.Our market strategies (such as recruiting and retention) are driven by our understanding of the possibilities for creating value for our students.

5.We respond rapidly to competitive actions that threaten us.

6.We constantly monitor our level of commitment and orientation to students.

7.University administration regularly discusses competitors' strengths and strategies.

8. All levels of administration understand how the entire institution can contribute to creating value for students.

9. We give close attention to service of students after enrollment.

10. Our strategy for competitive advantage is based on our understanding of our student's needs.

11.We encourage other staff and faculty outside of recruiting/administration to meet with our prospective students.

12.All of our departments are responsive to and integrated in serving students.

13.Information on recruiting successes and failures are communicated across functions in the business school/institution.

14.We share information and coordinate resource use with other units in the institution.

15.We target potential students where we have, or can develop a competitive advantage.

Each question answered on a 7 point scale: 1=Not At All, 7=To An Extreme Extent. Questions 1, 2, 4, 6, 9, and 10 relate to the Customer Orientation construct/dimension, Questions 3, 5, 7, 11, and 15 relate to the Competitor Orientation, Questions 8,12,13, and 14 relate to Organizational Coordination. The Overall Marketing Orientation score is computed by averaging the mean scores of the other three sets of questions. 